\title{
EVALUASI PENATALAKSANAAN IRIGASI KANDUNG KEMIH KARENA RETENSI BEKUAN DARAH PADA PASIEN GANGGUAN PERKEMIHAN : SYSTEMATIC REVIEW
}

1| M. Alfian Rajab, 2| Elly L Sjattar, 3| Abdul Majid, 4| Risnah

Email : alfianrajab103@gmail.com, ellyunhas@gmail.com, abdul.majidunhas@gmail.com, risnah@uin-alauddin.ac.id

\begin{abstract}
Clot retention is a common urological condition, if clot retention is left untreated, it can lead to severe pain, tachycardia, hypertension and bladder rupture, the most common cause of which is post-transurethral resection of the prostate (TURP). Thus, bladder irrigation is used to prevent obstruction, bleeding and clots that may occur after TURP surgery, and to maintain patency of the urinary catheter. Therefore, it is this systematic aim to evaluate the management of bladder irrigation due to clot retention in patients with urinary disorders. The research design was systematic reveiw based on PRISMA and question formulation using PICOT. The electronic databases used are Pubmed, Scincedirect, Proquest, Wiley and Google Scholar. With research inclusion criteria in accordance with research objectives, English, published in the last 10 years from 2010 2020 and full text. There were 6 articles reviewed, namely 2 articles with the cohort study method and 4 articles with the clinical trial / experimental study method. This systematic review shows that the Manual Bladder Washout (MBW) procedure is the main choice in the treatment of frequent blood clot retention, but there are various new alternative options such as the "thoracic catheter" technique, the "suction bridge" technique, CBI (continued bladder irrigation). based on wireless sensor, MBW (manual bladder irrigation) CATCH-22, modified irrigation fluid and modified Malecot catheter design.
\end{abstract}

\begin{tabular}{l}
$\qquad$ ARTICLE INFO \\
\hline Keywords: \\
Urinary disorders; Clot retention; \\
Bladder irrigation; Clot evacuation; \\
Clot retraction
\end{tabular}

DOI:

10.24252/kesehatan.v13i2.16482

\section{Pendahuluan}

Retensi bekuan darah adalah kondisi urologi yang umum. Retensi bekuan darah adalah ketidakmampuan membatalkan pembentukan bekuan darah di kandung kemih. Jika retensi gumpalan dibiarkan tidak diobati, itu dapat menyebabkan rasa sakit yang parah, takikardia, hipertensi dan ruptur kandung kemih (1). Gumpalan yang terbentuk di dalam kandung kemih menumpuk di sekitar dinding kandung kemih sehingga membatasi kontraksi detrusor. Kontraksi ini biasanya bertindak untuk menekan pembuluh darah yang melewatinya. Jika bekuan darah tidak dibersihkan dengan benar dan CBI dimulai, ada risiko kandung kemih yang berlebihan, membesar, dan berpotensi pecah. Ini adalah kejadian yang sangat berbahaya dan berpotensi fatal yang kemungkinan besar tidak dilaporkan dan tidak dikenali (2).

Etiologi gumpalan kandung kemih termasuk penyebab bedah dan penyebab non-bedah. Dari penyebab bedah, penyebab paling umum adalah pasca-transurethral reseksi prostat (TURP). Penyebab non-bedah adalah pendarahan saluran atas, pendarahan yang diinduksi oleh obat, pendarahan pasca-trauma, dan haematochyluria (3). TURP dianggap sebagai Gold Standart dan perawatan bedah pilihan untuk gejala klinis benign prostatic hyperplasia (BPH) (4). Prosedur pembedahan ini dilakukan dengan memasukkan resektoskopi melalui uretra untuk mengeksisi dan mengkauterisasi atau mereseksi kelenjar prostat yang mengalami obstruksi $(5,6)$.

Benign prostatic hyperplasia (BPH) merupakan penyakit umum pada pria yang lebih tua dengan umur lebih dari 50 tahun, ditandai oleh pembesaran prostat dan secara klinis terkait dengan gejala saluran kemih yang lebih rendah. BPH adalah diagnosis histologis yang mengacu pada proliferasi sel otot dan epitel dalam zona transisi prostat (7). Prevalensi histologi BPH meningkat sesuai dengan bertambahnya usia $50 \%$ dari pasien BPH berumur antara 50-60 tahun dan hanya $8 \%$ dari pasien BPH yang berumur dibawah 30 tahun (8). BPH mempengaruhi sekitar 70\% pria berusia 61 - 70 tahun dan 90\% pria berusia 81-90 tahun. Diperkirakan pada tahun 2025, BPH kemungkinan akan mempengaruhi $20 \%$ dari total populasi pria, walaupun BPH bukan penyakit yang mengancam jiwa, namun telah menjadi masalah kesehatan dan secara signifikan mempengaruhi kualitas hidup pasien. Bukti histologis peradangan telah dilaporkan pada sekitar $40 \%$ kasus BPH dan dikaitkan dengan peningkatan risiko retensi urin akut yang signifikan (9). 
TURP umumnya dikaitkan dengan efek samping pada pasien setelah operasi, sehingga opsi terapi tambahan untuk mencegah komplikasi sangat dibutuhkan. Sehingga, irigasi kandung kemih digunakan untuk mencegah obstruksi, mengeluarkan darah dan clots yang mungkin terjadi setelah proses pembedahan TURP, serta mempertahankan patensi kateter urin (10). Oleh karena itu, irigasi kateter adalah terapi lini pertama untuk retensi bekuan urin. Prosedur ini melibatkan penyisipan kateter ke dalam kandung kemih melalui uretra pasien, diikuti dengan irigasi manual kandung kemih menggunakan spuit 40-60 cc yang tersambung dengan kateter yang diisi dengan larutan garam atau air sampai bekuan dikeluarkan $(2,10)$. Dengan demikian, review sistematik ini dilakukan untuk memberikan informasi mengenai evaluasi penatalaksanaan irigasi kandung kemih karena retensi bekuan darah pada pasien gangguan perkemihan.

\section{Material dan Metode}

\section{a. Desain}

Literatur ini disusun menggunakan pedoman PRISMA untuk tinjauan sistematis (11). Formulasi pertanyaan mengikuti pedoman PICO (patient/problem, intervention, comparison/control dan outcome), adapun PICO dalam artikel ini adalah P: urinary disorders OR clot retention OR clots, I: bladder irrigation OR irrigation, C: -, O: clot evacuation OR clot retraction. Pencarian literatur dilakukan untuk mengidentifikasi evaluasi penatalaksanaan irigasi kandung kemih karena retensi bekuan darah pada pasien gangguan perkemihan. Database elektronik yang digunakan yaitu Pubmed, Wiley, Science Direct, Proquest dan Google Scholar. Teknik pencarian menggunakan sistem boolean, yaitu "OR", "AND". Selanjutnya dilakukan penilaian critical appraisal (CASP) $(12,13)$. Penulis juga memeriksa secara manual daftar referensi dari ulasan yang relevan dan termasuk studi untuk mengambil tambahan studi yang berpotensi memenuhi syarat (Tabel 1).

\begin{tabular}{cl}
\hline & \multicolumn{1}{c}{ Komponen PICO } \\
\cline { 2 - 2 } I & urinary disorders OR clot retention OR clots \\
C & bladder irrigation OR irrigation \\
O & clot evacuation OR clot retraction \\
\hline PICO (population, intervention, comparison, and outcome)
\end{tabular}

Tabel 1. Deskripsi kata kunci yang digunakan dalam pencarian literatur menggunakan metode PICO

\section{b. Kriteria inklusi/kriteria eksklusi}

Kriteria inklusi penelitian sesuai dengan tujuan penelitian, bahasa Inggris, diterbitkan 10 tahun terakhir dari tahun 2010-2020 dan full teks. Selanjutnya membuat screening diagram flow yang berpedoman pada PRISMA (11). Jumlah artikel yang ditemukan pada lima database kemudian dipilih jurnal yang relevan melalui beberapa sreening meliputi, screening duplikasi judul, screening full text, screening judul yang sesuai dengan topik, screening abstrak yang sesuai dengan topik, screening 10 tahun terakhir yaitu dari 2010-2020, berbahasa inggris, sehingga didapat jurnal yang relevan untuk dilakukan review.

\section{c. Strategi pencarian}

Strategi pencarian yang dilakukan untuk mengakses publikasi terdiri dari tiga tahap yaitu:

1) Pencarian pada Medline dan nursing journals serta ditentukan tahun pencariannya 10 tahun terakhir, digunakan untuk mengidentifikasi kata-kata kunci dalam judul dan pertanyaan penelitian.

2) Sinonim dan istilah kata kunci digunakan dalam pencarian literatur.

3) Daftar referensi dan kutipan artikel di kumpulkan dari hasil pencarian pada tahap dua. 
Adapun istilah pencariannya adalah sebagai berikut: ((c((urinary disorders[MeSH Terms]) OR clot retention[MeSH Terms]) OR clots[MeSH Terms])) AND ((bladder irrigation[MeSH Terms]) OR irrigation[MeSH Terms])) AND ((clot evacuation[MeSH Terms]) OR clot retraction[MeSH Terms]). Salinan dari pencarian literatur yang memenuhi kriteria inklusi dan diidentifikasi selama pencarian digunakan untuk sintesis data. Literatur yang ditemukan dalam daftar referensi dipertimbangkan untuk diambil sebagai bahan untuk dilakukan literatur review selama literatur tersebut relefan.

\section{Hasil}

\section{a. Seleksi studi}

Seleksi artikel digambarkan pada Gambar 1 diagram flow. Total 215 artikel yang diidentifikasi terdapat 17 artikel dieksklusi karena doubel publikasi, 21 artikel tidak full text, 158 artikel tidak sesuai pertanyaan penelitian, 12 artikel bukan bahasa inggris, dan 1 artikel bukan hasil penelitian. Sehingga tersisa 6 artikel yang direview penulis. Keenam artikel dipublikasikan antara tahun 2011 sampai 2019 dengan desain penelitian: 2 artikel dengan metode cohort study dan 4 artikel dengan metode clinical trial/eksperimental study. Keenam artikel yang memenuhi kriteria dirangkum dalam Tabel 2 (sintesis grid) dengan memaparkan nama penulis, tahun publikasi, tempat (negara), judul, tujuan, populasi dan setting, intervensi dan metode, dan hasil penelitian.

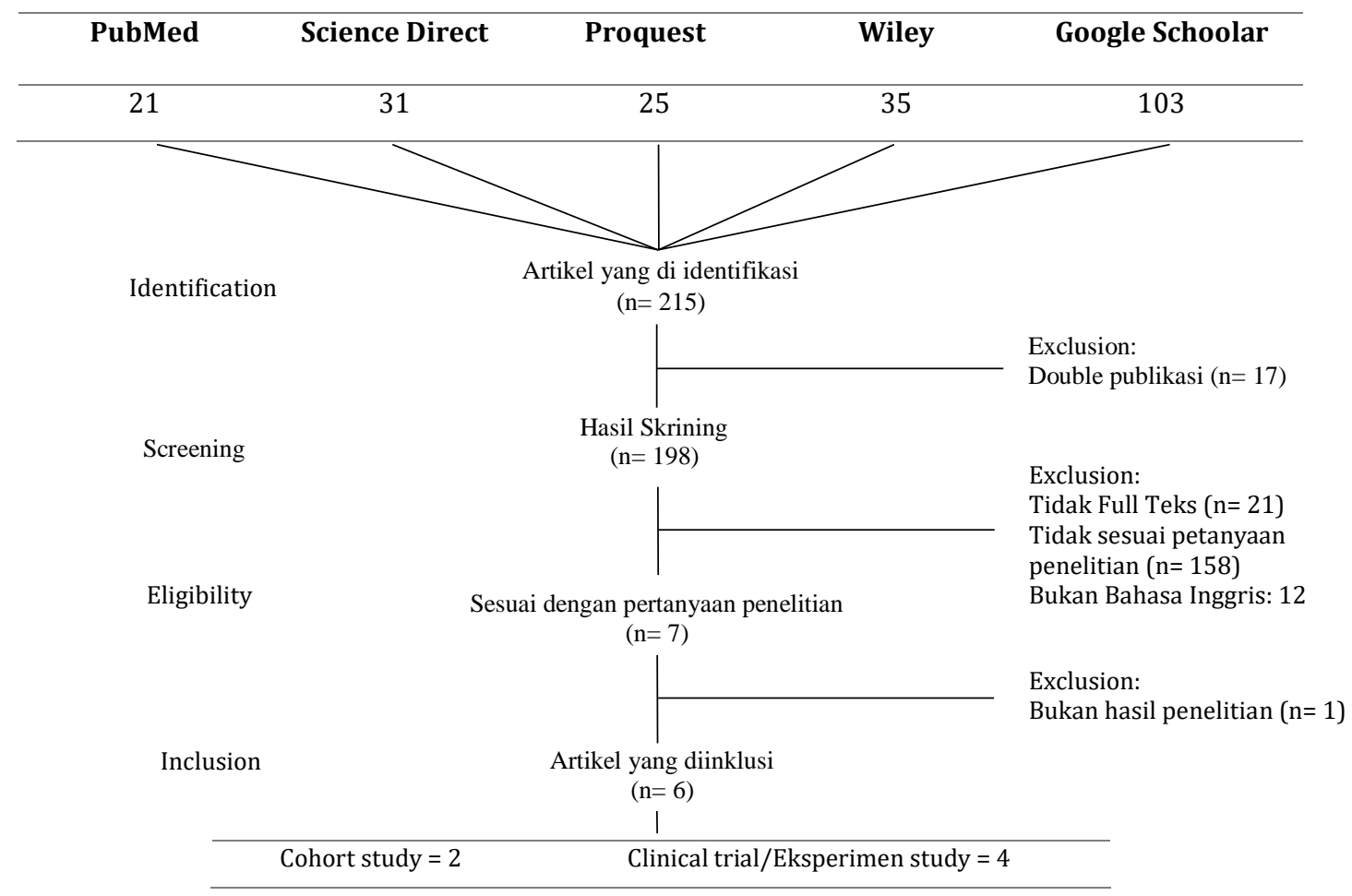

Gambar 1: Diagram flow untuk inklusi dan eksklusi

\section{b. Karakteristik Studi}

Karakteristik studi dipaparkan dengan jelas pada Tabel 2 (sintesis grid). Dari Keenam artikel menggambarkan penatalaksanaan irigasi kandung kemih karena retensi bekuan darah pada pasien gangguan perkemihan dari berbagai negara seperti Turki, Australia, USA, India dan Cina. Retensi bekuan darah banyak ditemukan pada kasus seperti pasca operasi TURP (transurethral resection of the prostate), pasca operasi TURBT (transurethral resection of a 
bladder tumor), bladder tumor dan lainnya (pendarahan saluran atas, pendarahan yang diinduksi oleh obat atau pasca-trauma) (3). Berdasarkan temuan dari artikel yang direview terdapat berbagai alternative dan penemuan baru dalam penanganan retensi bekuan darah, seperti teknik "thoracic catheter" (3), teknik "suction bridge" (14), CBI (continued bladder irrigation) berbasis wireless sensor (15), MBW (manual bladder irrigation) CATCH-22 (2), modifikasi cairan irigasi (16) dan modifikasi desain kateter Malecot (17).

\section{1) Teknik "thoracic catheter"}

Teknik operasi adalah sebagai berikut: pasien disimpan dalam posisi litotomi di ruang pemeriksaan atau berbaring di tempat tidur mereka sendiri (Gambar 1). Prosedur ini diterapkan dengan anestesi lokal dengan menggunakan 2\% lidocaine gel, dan 22F atau 24F kateter toraks digunakan. Pertama, ujung kateter toraks dipotong menjadi setengah lingkaran kira-kira $2 \mathrm{~cm}$ oleh gunting (Gambar 2). Kateter toraks dimasukkan ke dalam kandung kemih dan kemudian dihubungkan ke spuit 50cc (Gambar 1-3). Untuk mencuci kandung kemih dan mengevakuasi bekuan, penyedotan dimulai dengan menggunakan larutan garam steril ( $\mathrm{NaCl}$ 0,9\%) menggunakan spuit. Gumpalan itu langsung disedot. Ujung kateter toraks dipindahkan ke samping, ke atas dan ke bawah untuk lebih menghancurkan gumpalan. Kita bisa melihat/meraba kandung kemih yang dikosongkan. Kateter toraks mengevakuasi gumpalan tanpa menyebabkan trauma atau cedera pada kandung kemih. Pada akhir prosedur, kateter Foley tiga arah dimasukkan dan mulai irigasi kandung kemih dengan normal salin (3).

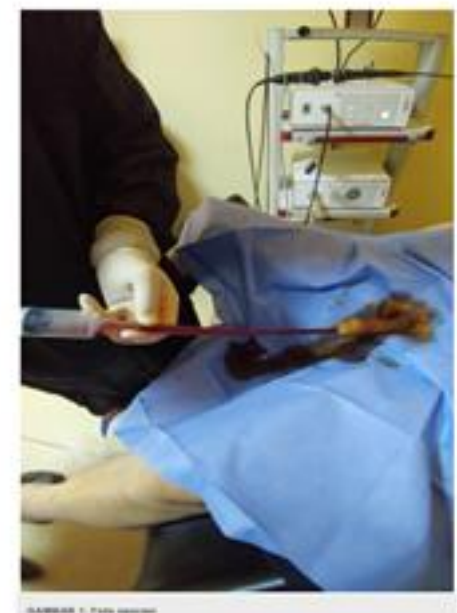

(Gambar 1)

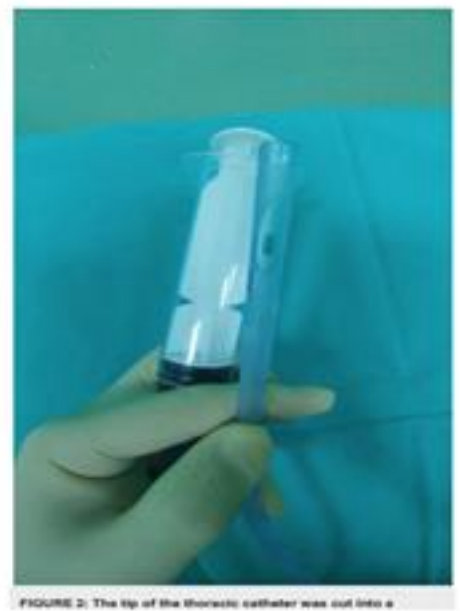

(Gambar 2)

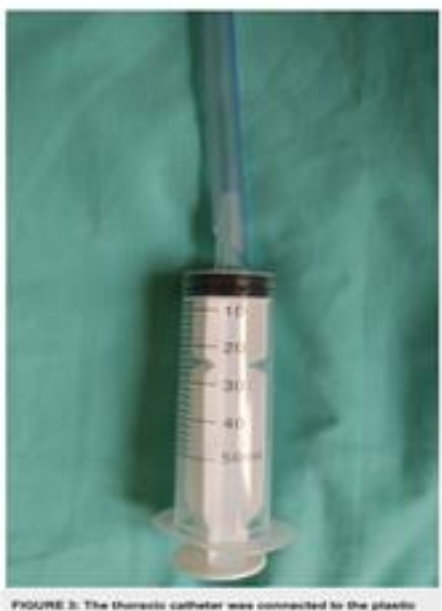

(Gambar 3)

2) Teknik "suction bridge"

Berdasarkan konsep Apul Goel (Gbr. 1a), Karl Storz Gmbh \& Co. membuat "suction bridge" (Gbr. 1b). Perangkat itu diperlukan karena tidak ada konektor yang tersedia secara komersial yang dapat memastikan hubungan yang erat antara selubung sistoskopi dan pipa hisap (Gbr. 1c). Perangkat baru ini memiliki ventilasi udara di bagian atas (panah) yang ditutup dengan jari telunjuk pada saat pengisapan dan dilepaskan secara intermiten (dengan mengangkat jari) untuk menghindari cedera kandung kemih. Salah satu ujung perangkat memiliki kunci lebih besar untuk dipasang dengan selubung cystoscope, sementara di ujung lainnya tabung hisap dipasang (Gbr. 1d).

Untuk menghilangkan bekuan darah, sistoskopi dilakukan menggunakan selubung 25-F untuk menilai volume bekuan darah. Lensa sistoskopi bersama dengan bridge kemudian dilepas dan selubung 25-F dibiarkan in situ (ukuran selubung apa pun dapat digunakan; semakin besar, semakin baik). Selubung ini kemudian dihubungkan ke penghisapan 
mekanis menggunakan "suction bridge" (Gbr. 1d). Hisap dimulai pada $250 \mathrm{mmHg}$ (meningkat menjadi $400 \mathrm{mmHg}$, jika perlu). Kandung kemih terus terisi selama prosedur dengan secara teratur menghentikan pengisapan dan mengisi kandung kemih dengan salin normal melalui saluran samping sistoskopi. Sistoskopi rutin dilakukan untuk memeriksa sisa gumpalan dan integritas dinding kandung kemih. Pada akhir prosedur, kateter Foley triway dibiarkan diam dan irigasi kandung kemih dimulai (14).

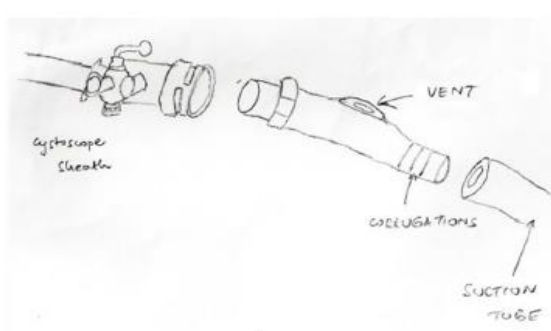

A

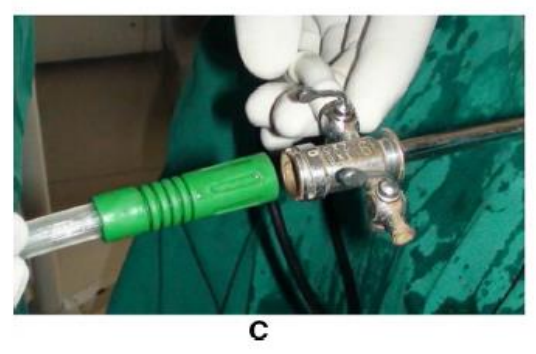

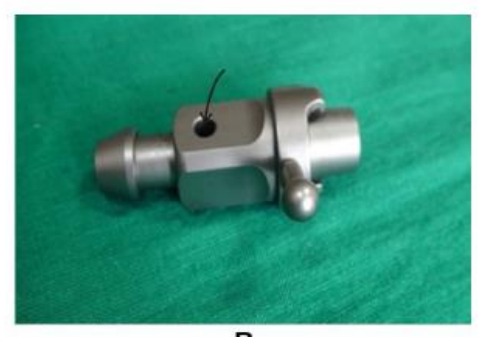

B

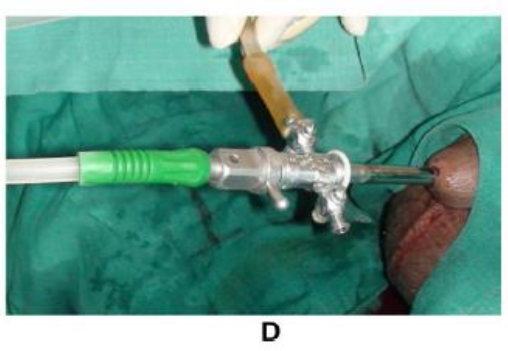

3) CBI (continued bladder irrigation) berbasis wireless sensor

Laju aliran irigasi kandung kemih dikendalikan menggunakan perangkat pengatur otomatis. Peralatan irigasi kandung kemih otomatis yang diterapkan dengan sistem sensor nirkabel terdiri dari 3 modul, termasuk monitor warna untuk solusi drainase, pengontrol penyesuaian laju cairan flushing, dan mikroprosesor komputer. Setelah TURP, pasien ditempatkan di tempat tidur rumah sakit. Monitor warna dipasang pada evakuasi kateter, dan pengontrol penyesuaian irigasi dipasang di Murphy dropper jalur pembilasan. Sinyal cahaya untuk perubahan warna ditangkap oleh sensor frekuensi/cahaya dan dianalisis oleh mikroprosesor komputer untuk secara otomatis menyesuaikan laju irigasi. Parameter sistem ditetapkan oleh para ahli sesuai dengan kondisi masing-masing pasien (15).

4) MBW (manual bladder irrigation) CATCH-22

Protokol standar manual pencucian kandung kemih (2) :

$\mathrm{C}$ = Catheter type and size: Minimum $22 \mathrm{~F}$ kateter - ditingkatkan ukurannya jika perlu

$\mathrm{A}=$ Aseptic technique, analgesia, antibiotics

$\mathrm{T}$ = Twisting/catheter manipulation: Manipulasi/memutar kateter selama pencucian. Deflasi balon dan pencabutan IDC untuk membersihkan leher kandung kemih

$\mathrm{C}=$ Clot $+1 \mathrm{~L}$ rule: Minimal $1 \mathrm{~L}$ pencucian salin steril setelah gumpalan terakhir berlalu

$\mathrm{H}=$ Help: Dapatkan bantuan di dekat Anda

22 = Pertimbangkan setidaknya kateter $22 \mathrm{~F}$ pada awalnya

5) Modifikasi cairan irigasi

Kandung kemih diirigasi dengan $40.000 \mathrm{U}$ chymotrypsin dalam $50 \mathrm{~mL}$ natrium bikarbonat 5\% menggunakan kateter Foley (20F-24F) selama 30 menit. Gumpalan itu kemudian mudah dimobilisasi dan dievakuasi menggunakan irigasi normal salin secara 
terus menerus dan hisap dengan jarum suntik $60 \mathrm{~mL}$. Prosedur ini diulangi 2-4 kali sampai semua gumpalan darah telah dievakuasi (16).

6) Modifikasi desain kateter Malecot

Dua versi modifikasi dari desain kateter Malecot yang melibatkan 2 dan 4 lubang tambahan juga diuji untuk menentukan efek dari desain hybrid 6-hole / Malecot (17).
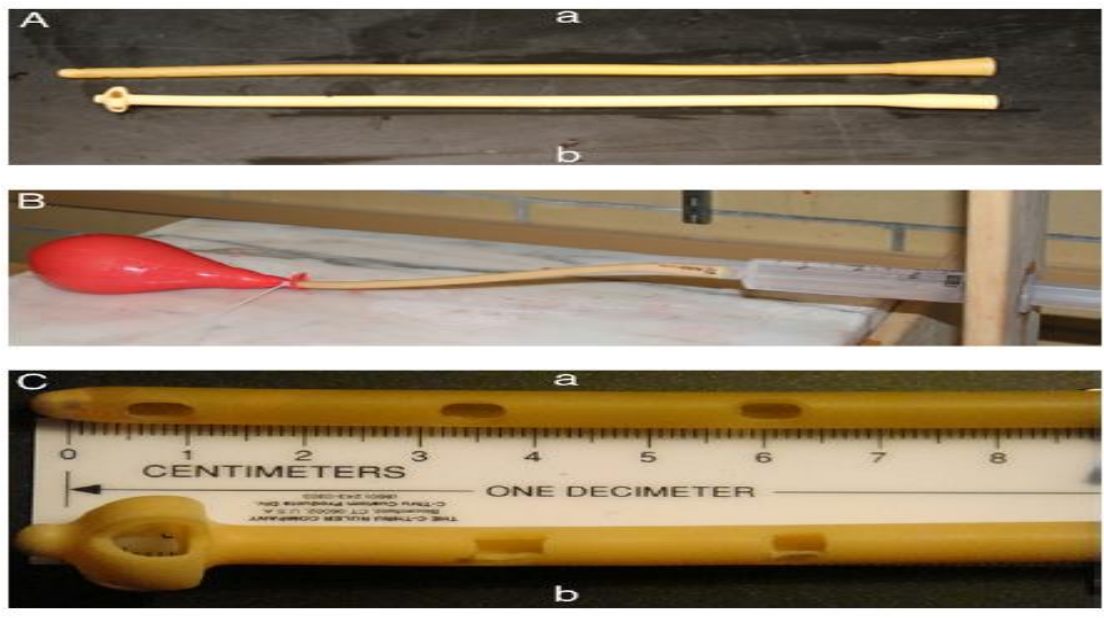

Gambar A : desain kateter Malecot (a) dan kateter 6-lubang (b).

Gambar B : model kandung kemih lateks dengan ujung kateter diamankan di leher. Alat irigasi terdiri dari papan kayu stasioner untuk menahan jarum suntik ujung kateter 60 cc secara horizontal sekitar 6 inci di atas balon.

Gambar C : kateter 6 lubang standar (a) dan desain Malecot yang dimodifikasi dengan 4 lubang tambahan (b).

\section{Diskusi}

Tinjauan sistematis ini bertujuan untuk mengevaluasi penatalaksanaan irigasi kandung kemih karena retensi bekuan darah pada pasien gangguan perkemihan. Retensi bekuan darah dapat terjadi sebagai komplikasi setelah pembedahan urologis (TURP/TURBT) atau dikarenakan keganasan/tumor, koagulopati, kalkulus atau infeksi. Pada umumnya hal ini menyakitkan bagi pasien dan jika tidak ditangani secara memadai dapat menyebabkan perdarahan lebih lanjut, pembekuan dan retensi yang berlanjut, bahkan terjadi ketika kateter dengan irigasi terus menerus dalam pengawasan. Manual bladder irigasi untuk retensi bekuan urin merupakan keterampilan integral untuk urologis dan perawat urologi. Satu studi mengidentifikasi bahwa tindakan MBW sebagai aktivitas rutin yang dilakukan oleh $80,4 \%$ perawat dalam mengatasi retensi bekuan darah (18).

MBW dilakukan oleh perawat urologi karena hal ini bisa dilakukan dengan mudah disamping tempat tidur pasien tanpa menggunakan anastesi, dengan dorongan lembut dalam kateter menggunakan spuit 40-60 ml $(10,16)$. Dari penjelasan tersebut, bukti ini menunjukkan bahwa intervensi MBW masih menjadi pilihan alternative dalam penanganan retensi bekuan darah pada pasien. Dari hasil survey yang dilakukan oleh Dungerwalla et al., (2016), menunjukkan bahwa efektifitas MBW tidak akan sepenuhnya berhasil apabila perawat tidak melakukan dengan tepat, padahal hal ini penting untuk mengetahui sejauh mana keberhasilan MBW yang telah dilakukan, karena setiap upaya MBW memiliki potensi untuk menyebabkan uretra, kandung kemih bahkan prostat menjadi trauma jika tidak dilakukan dengan hati-hati. Sebanyak 72\% perawat yang disurvei percaya bahwa MBW selesai ketika irigasi terus menerus berjalan bebas. Studi ini juga menemukan bahwa hampir 70\% dari staf perawat dan $43 \%$ dari pendaftar bedah keliru berpikir bahwa CBI membantu dalam mengevakuasi gumpalan kecil dari kandung 
kemih. Kurangnya pengetahuan seputar penggunaan CBI sangat memprihatinkan dan menyoroti perlunya pendidikan yang lebih baik.

Selain daripada teknik MBW, temuan lain dalam sistematik review ini merupakan sebuah inovasi baru dan masih terbatasnya penelitian yang sama. Terdapat dua temuan yang membandikan antara teknik baru dengan teknik konvensional, yaitu teknik "thoracic catheter" dan teknik "suction bridge", kedua teknik tersebut menjadikan Jarum suntik Toomey atau evakuator Ellick sebagai pembanding dari hasil yang ditemukan. Sedangkan, CBI (continued bladder irrigation) berbasis wireless sensor dilaporkan baru untuk pertama kalinya dan diuji klinis pada pasien pasca TURP dengan hasil tidak ada perbedaan signifikan dalam hal waktu irigasi dan lama rawat inap antara kelompok intervensi dan kelompok kontrol, yang menunjukkan bahwa sistem irigasi otomatis tidak memperpanjang waktu irigasi dan masa tinggal pasien di rumah sakit (15). Hasil ini sangat bermanfaat dalam penatalaksanaan CBI karena fakta bahwa dengan CBI konvensional, laju aliran diatur pada kebebasan berdasarkan pengalaman subjektif. Berdasarkan pengalaman klinis, personel perawatan medis atau anggota keluarga pasien cenderung untuk mengatur laju aliran lebih cepat daripada nilai teori, yang dapat meningkatkan volume irigasi. Namun, laju aliran cepat tidak dapat mencegah komplikasi irigasi kandung kemih. Sistem CBI berbasis wireless sensor (otomatis) ditandai dengan kontrol yang akurat, monitor waktu, dan penyesuaian otomatis.

Temuan selanjutnya yaitu modifikasi cairan irigasi, solusi irigasi yang paling banyak digunakan adalah normal saline steril, Namun, laporan kasus telah mendokumentasikan penggunaan hidrogen peroksida yang aman dan efektif (20). Sebuah studi percontohan juga menggambarkan penggunaan "alteplase" (aktivator plasminogen jaringan) untuk menghilangkan bekuan yang lebih baik bila dibandingkan dengan normal salin (1). Sementara solusi irigasi alternatif terus diujicobakan dalam literatur, oleh karenanya kami merekomendasikan penggunaan normal salin steril yang tersedia secara luas dan hemat biaya sebagai solusi aman untuk MBW dan CBI. Dari semua artikel yang direview dilaporkan bahwa penatalaksanaan irigasi kandung kemih menghilangkan bekuan darah dengan hasil yang sukses, aman, sederhana, dapat diterapkan serta tidak perlu keahlian khusus untuk mempelajari metode/teknik tersebut $(2,3,14-17)$. Namun dengan demikian, temuan tersebut belum dapat dijadikan sebagai evidence based practice diperlukan penelitian lebih lanjut diberbagai daerah dengan sampel yang lebih banyak.

\section{Kesimpulan dan Saran}

Tinjauan sistematik ini menunjukkan bahwa tindakan Manual Bladder Washout (MBW) menjadi pilihan utama dalam penanganan retensi bekuan darah yang sering dilakukan, namun terdapat berbagai pilihan alternative yang baru seperti teknik "thoracic catheter", teknik "suction bridge", CBI (continued bladder irrigation) berbasis wireless sensor, MBW (manual bladder irrigation) CATCH-22, modifikasi cairan irigasi dan modifikasi desain kateter Malecot. Oleh karenanya, perlunya penelitian lebih lanjut akan temuan alternative sehingga dapat dijadikan menjadi acuan dan evidence based practice dalam intervensi keperawatan.

\section{Keterbatasan Penelitian}

Penelitian ini juga memiliki keterbatasan yaitu tidak adanya artikel dengan metode RCT yang direview dan jumlah artikel yang direview masih terbatas (kurang) dalam mengevaluasi penatalaksanaan irigasi kandung kemih karena retensi bekuan darah pada pasien gangguan perkemihan.

\section{Implikasi untuk Praktek}

Dalam praktik keperawatan saat ini, tindakan MBW merupakan aktivitas rutin yang dilakukan oleh perawat urologi dalam mengatasi retensi bekuan darah, namun berdasarkan pada temuan sistematik ini didapatkan tindakan alternative yang baru. Dilaporkan bahwa hasilnya sukses, 
aman, sederhana dan dapat diterapkan serta tidak perlu keahlian khusus untuk mempelajari metode/teknik tersebut, akan tetapi kurangnya penelitian dan terbatasnya alat yang digunakan dalam temuan sistematik ini sehingga temuan tersebut belum dapat dijadikan sebagai evidence based practice, perlu penelitian serupa yang lebih lanjut dengan metode RCT (randomoised control trial) dan dari latar belakang populasi dan tempat penelitian yang berbeda dan pengadaan alat yang digunakan.

CASP (critical appraisal skills programme) Checklist : RCT (randomised controlled trial) (12)

\begin{tabular}{|c|c|c|c|c|c|}
\hline No & Appraisal Checklist & $\begin{array}{l}\text { Ding et al., } \\
\text { (2016) }\end{array}$ & $\begin{array}{l}\text { Goel \& } \\
\text { Dalela, } \\
\text { (2015) } \\
\text { (14) }\end{array}$ & $\begin{array}{l}\text { Bo et al., } \\
(2014) \\
(16)\end{array}$ & $\begin{array}{l}\text { Mesfin } \\
\text { et al., } \\
(2011) \\
(17)\end{array}$ \\
\hline 1. & $\begin{array}{l}\text { Did the trial address a clearly focused } \\
\text { issue? }\end{array}$ & yes & yes & yes & yes \\
\hline 2. & $\begin{array}{l}\text { Was the assignment of patients to } \\
\text { treatments randomised? }\end{array}$ & yes & can't tell & can't tell & no \\
\hline 3. & $\begin{array}{l}\text { Were all of the patients who entered the } \\
\text { trial properly accounted for at its } \\
\text { conclusion? }\end{array}$ & yes & yes & yes & no \\
\hline 4. & $\begin{array}{l}\text { Were patients, health workers and study } \\
\text { personnel 'blind' to treatment? }\end{array}$ & no & no & no & no \\
\hline 5. & $\begin{array}{l}\text { Were the groups similar at the start of the } \\
\text { trial }\end{array}$ & yes & no & no & no \\
\hline 6. & $\begin{array}{l}\text { Aside from the experimental intervention, } \\
\text { were the groups treated equally? }\end{array}$ & no & no & no & no \\
\hline 7. & How large was the treatment effect? & yes & yes & yes & yes \\
\hline 8. & $\begin{array}{l}\text { How precise was the estimate of the } \\
\text { treatment effect? }\end{array}$ & can't tell & can't tell & can't tell & yes \\
\hline 9. & $\begin{array}{l}\text { Can the results be applied to the local } \\
\text { population, or in your context? }\end{array}$ & yes & yes & yes & yes \\
\hline 10. & $\begin{array}{l}\text { Were all clinically important outcomes } \\
\text { considered? }\end{array}$ & yes & yes & yes & yes \\
\hline 11. & $\begin{array}{l}\text { Are the benefits worth the harms and } \\
\text { costs? }\end{array}$ & yes & yes & yes & yes \\
\hline
\end{tabular}

CASP (critical appraisal skills programme) Checklist : cohort study (13)

\begin{tabular}{|c|c|c|c|}
\hline No & Appraisal Checklist & $\begin{array}{c}\text { Aydin et al., } \\
(2019)(3)\end{array}$ & $\begin{array}{l}\text { Clarebrough et } \\
\text { al., (2018) (2) }\end{array}$ \\
\hline 1. & Did the study address a clearly focused issue? & yes & yes \\
\hline 2. & Was the cohort recruited in an acceptable way? & yes & yes \\
\hline 3. & Was the exposure accurately measured to minimise bias? & can't tell & yes \\
\hline 4. & Was the outcome accurately measured to minimise bias? & can't tell & yes \\
\hline $5 . \mathrm{a}$ & $\begin{array}{l}\text { Have the authors identified all important confounding } \\
\text { factors? }\end{array}$ & yes & yes \\
\hline $5 . \mathrm{b}$ & $\begin{array}{l}\text { Have they taken account of the confounding factors in } \\
\text { the design and/or analysis? }\end{array}$ & no & yes \\
\hline $6 . \mathrm{a}$ & Was the follow up of subjects complete enough? & yes & yes \\
\hline 6.b & Was the follow up of subjects long enough? & can't tell & yes \\
\hline 7. & What are the results of this study? & yes & yes \\
\hline 8. & How precise are the results? & yes & yes \\
\hline 9. & Do you believe the results? & can't tell & yes \\
\hline 10. & Can the results be applied to the local population? & can't tell & yes \\
\hline 11. & $\begin{array}{l}\text { Do the results of this study fit with other available } \\
\text { evidence? }\end{array}$ & can't tell & yes \\
\hline 12. & What are the implications of this study for practice? & yes & yes \\
\hline
\end{tabular}


Tabel 2. Sintesis Grid

\begin{tabular}{|c|c|c|c|c|c|}
\hline $\begin{array}{l}\text { Peneliti, tahun; Negara } \\
\text { Judul }\end{array}$ & Metode & Tujuan & Partisipan & Intervensi & Hasil Penelitian \\
\hline $\begin{array}{l}\text { Aydin et al., (2019) ; Turki } \\
\text { (3) } \\
\text { Clot Retention: Our } \\
\text { Experiences with a Simple } \\
\text { New Technique of } \\
\text { Evacuation with a Thoracic } \\
\text { Catheter }\end{array}$ & $\begin{array}{l}\text { Retrospective } \\
\text { cohort study }\end{array}$ & $\begin{array}{l}\text { Untuk } \\
\text { menggambarkan } \\
\text { teknik alternatif } \\
\text { untuk menghilangkan } \\
\text { bekuan yang kencang } \\
\text { dan kronis dengan } \\
\text { menggunakan teknik } \\
\text { kateter toraks }\end{array}$ & $\begin{array}{llr}\text { Antara Januari } & 2011 \\
\text { dan Juni } & 2018, \\
\text { sebanyak } 27 & \text { pasien } \\
\text { retensi dirawat dengan } \\
\text { anestesi lokal dengan } \\
\text { teknik kateter toraks }\end{array}$ & $\begin{array}{l}\text { Prosedur diterapkan dengan anestesi } \\
\text { lokal 2\% lidocaine gel, dan } \\
\text { menggunakan } 22 \text { atau } 24 \text { French } \\
\text { kateter toraks. Pertama, sisi ujung } \\
\text { kateter toraks dipotong menjadi } \\
\text { setengah lingkaran kira-kira } 2 \mathrm{~cm} \\
\text { dengan gunting. Kateter toraks } \\
\text { dimasukkan ke dalam kandung kemih } \\
\text { dan kemudian dihubungkan ke spuit } \\
50 \text { cc. Untuk mencuci kandung kemih } \\
\text { dan mengevakuasi bekuan, } \\
\text { penyedotan dimulai dengan } \\
\text { menggunakan larutan garam steril. }\end{array}$ & $\begin{array}{l}\text { Dua puluh tujuh pasien dengan } \\
\text { usia rata-rata } 58 \text { tahun (kisaran } \\
45-70 \text { ) dimasukkan. Etiologi } \\
\text { gumpalan kandung kemih } \\
\text { termasuk penyebab bedah dan } \\
\text { penyebab non-bedah. Dari } \\
\text { penyebab bedah, penyebab paling } \\
\text { umum adalah pasca-transurethral } \\
\text { resection of the prostate (TURP). } \\
\text { Penyebab nonsurgical adalah } \\
\text { pendarahan saluran atas, } \\
\text { pendarahan yang diinduksi oleh } \\
\text { obat, pendarahan pasca-trauma, } \\
\text { dan haematochyluria. } \\
\text { Ditemukan bahwa teknik kateter } \\
\text { toraks sederhana dan mudah } \\
\text { diadopsi, tanpa pelatihan yang } \\
\text { diperlukan. }\end{array}$ \\
\hline $\begin{array}{l}\text { Ding et al., (2016) ; China } \\
\text { (15) } \\
\text { A novel automatic } \\
\text { regulatory device for } \\
\text { continuous bladder } \\
\text { irrigation based on } \\
\text { wireless sensor in patients } \\
\text { after transurethral } \\
\text { resection of the prostate }\end{array}$ & $\begin{array}{l}\text { Clinical trial / } \\
\text { Experimental } \\
\text { Study }\end{array}$ & 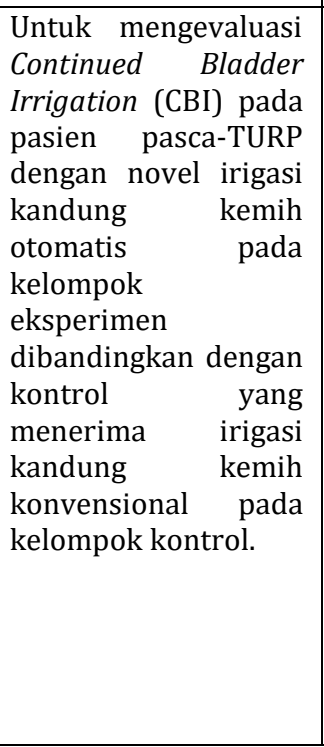 & $\begin{array}{l}\text { Antara Juli } 2013 \text { dan } \\
\text { Juli 2014, sebanyak } 146 \\
\text { pasien secara acak } \\
\text { dibagi menjadi } 2 \\
\text { kelompok yaitu } \\
\text { kelompok eksperimen } \\
(\mathrm{n}=76) \text { dan kelompok } \\
\text { kontrol }(\mathrm{n}=70) \text {. }\end{array}$ & $\begin{array}{l}\text { - Kelompok Kontrol : } \\
\text { Tingkat irigasi awalnya dikelola } \\
\text { pada 150dpm dalam } 2 \text { jam pasca } \\
\text { operasi. Pada } 2 \text { hingga } 8 \text { jam } \\
\text { setelah operasi, laju penurunan } \\
\text { elusi dipertahankan pada } 120 \mathrm{dpm} \text {. } \\
\text { Tingkat irigasi } r \text { kemudian } \\
\text { disesuaikan dalam } 30 \mathrm{dpm} \\
\text { berdasarkan warna larutan } \\
\text { drainase. Ketika cairan flushing } \\
\text { jernih atau menunjukkan warna } \\
\text { kemerahan, irigasi kandung kemih } \\
\text { dihentikan. } \\
\text { Kelompok Intervensi : } \\
\text { Laju aliran irigasi kandung kemih } \\
\text { dikendalikan menggunakan } \\
\text { perangkat pengatur otomatis. } \\
\text { Peralatan irigasi kandung kemih } \\
\text { otomatis yang diterapkan dengan } \\
\text { sistem sensor nirkabel terdiri dari }\end{array}$ & $\begin{array}{l}\text { Volume irigasi rata-rata dari } \\
\text { kelompok eksperimen }(24,2 \pm 3,8 \\
\text { L) secara signifikan lebih rendah } \\
\text { daripada kontrol }(54,6 \pm 5,4 \mathrm{~L})(\mathrm{P} \\
<0,05) \text {. Pasien yang diobati } \\
\text { dengan alat irigasi otomatis } \\
\text { mengalami penurunan kejadian } \\
\text { retensi bekuan }(8 / 76) \text { dan } \\
\text { sistospasme secara signifikan } \\
(12 / 76) \text { dibandingkan dengan } \\
\text { kontrol }(21 / 70 ; 39 / 70, \mathrm{P}<0,05) \text {. } \\
\text { Tidak ada perbedaan yang } \\
\text { signifikan antara } 2 \text { kelompok } \\
\text { sehubungan dengan waktu irigasi } \\
(28,6 \pm 2,7 \text { vs } 29,5 \pm 3,4 \text { jam, } \mathrm{P}= \\
0,077) .\end{array}$ \\
\hline
\end{tabular}




\begin{tabular}{|c|c|c|c|c|c|}
\hline & & & & $\begin{array}{l}3 \text { modul, termasuk monitor warna } \\
\text { untuk solusi drainase, pengontrol } \\
\text { penyesuaian laju cairan flushing, } \\
\text { dan mikroprosesor komputer. } \\
\text { Setelah TURP, pasien ditempatkan } \\
\text { di tempat tidur rumah sakit biasa. } \\
\text { Monitor warna dipasang pada } \\
\text { evakuasi kateter, dan pengontrol } \\
\text { penyesuaian irigasi dipasang di } \\
\text { Murphy dropper jalur pembilasan. } \\
\text { Sinyal cahaya untuk perubahan } \\
\text { warna ditangkap oleh sensor } \\
\text { frekuensi / cahaya dan dianalisis } \\
\text { oleh mikroprosesor komputer } \\
\text { untuk secara otomatis } \\
\text { menyesuaikan laju irigasi. } \\
\text { Parameter sistem ditetapkan oleh } \\
\text { para ahli sesuai dengan kondisi } \\
\text { masing-masing pasien. }\end{array}$ & \\
\hline $\begin{array}{l}\text { Goel \& Dalela, (2015) ; } \\
\text { India (14) } \\
\text { Mechanical suction for clot } \\
\text { evacuation: experience } \\
\text { with "suction bridge" for } \\
\text { safe and effective clot } \\
\text { removal }\end{array}$ & Clinical trial & $\begin{array}{l}\text { Untuk menyajikan } \\
\text { pengalaman dengan } \\
\text { menggunakan } \\
\text { "suction bridge" } \\
\text { untuk menghilangkan } \\
\text { bekuan kandung } \\
\text { kemih }\end{array}$ & $\begin{array}{l}\text { Selama periode } 18 \\
\text { bulan, jembatan hisap } \\
\text { digunakan pada } 25 \\
\text { pasien berturut-turut } \\
\text { yang memiliki bekuan } \\
\text { darah di kandung } \\
\text { kemih. }\end{array}$ & $\begin{array}{l}\text { - Kelompok intervensi : } \\
\text { Pada semua pasien dengan } \\
\text { gumpalan kandung kemih, hisap } \\
\text { mekanis dilakukan menggunakan } \\
\text { "jembatan hisap". Jembatan ini } \\
\text { memiliki kunci luer yang dipasang } \\
\text { pada selubung sistoskop, dan ujung } \\
\text { lainnya terhubung ke tabung isap. } \\
\text { Tekanan hisap dimulai pada } 250 \\
\text { mmHg dan ditingkatkan hingga } 400 \\
\text { mmHg jika diperlukan. } \\
\text { - Kelompok kontrol : - (tidak ada) }\end{array}$ & $\begin{array}{l}\text { Dua puluh lima pasien dengan } \\
\text { usia rata-rata 59,4 tahun } \\
\text { dimasukkan. Etiologi gumpalan } \\
\text { kandung kemih termasuk tumor } \\
\text { kandung kemih dalam sembilan, } \\
\text { benign prostate hyperplasia } \\
\text { (BPH) di dua, BPH dengan batu } \\
\text { kandung kemih dalam satu, } \\
\text { hematochyluria dalam tiga, dan } \\
\text { reseksi prostat pasca } \\
\text { transurethral dalam sepuluh. } \\
\text { Terdapat delapan belas pasien } \\
\text { disajikan dalam retensi } \\
\text { gumpalan. Perkiraan ukuran } \\
\text { gumpalan berkisar antara } 50 \text { mL } \\
\text { hingga lebih dari } 1 \text { L. Durasi rata- } \\
\text { rata untuk menghilangkan } \\
\text { gumpalan adalah 15 menit } \\
\text { (kisaran 5-60). Prosedur ini } \\
\text { berhasil pada semua pasien. } \\
\text { Tidak ada cedera kandung kemih. }\end{array}$ \\
\hline
\end{tabular}




\begin{tabular}{|c|c|c|c|c|c|}
\hline $\begin{array}{l}\text { Clarebrough et al., (2018); } \\
\text { Australia (2) } \\
\text { CATCH-22: a manual } \\
\text { bladder washout protocol } \\
\text { to improve care for clot } \\
\text { retention }\end{array}$ & $\begin{array}{l}\text { Prospective } \\
\text { cohort study }\end{array}$ & $\begin{array}{l}\text { - Untuk meninjau } \\
\text { praktik saat ini } \\
\text { dalam Manual } \\
\text { Bladder Washout } \\
(\text { MBW) untuk } \\
\text { hematuria dengan } \\
\text { retensi bekuan } \\
\text { darah, } \\
\text { membandingkan } \\
\text { yang dilakukan } \\
\text { oleh unit urologi } \\
\text { dengan layanan } \\
\text { rawat inap lainnya. } \\
\text { - Untuk } \\
\text { menggambarkan } \\
\text { protokol standar } \\
\text { untuk MBW. }\end{array}$ & $\begin{array}{l}\text { Data dikumpulkan } \\
\text { secara prospektif dalam } \\
\text { satu institusi. Dua } \\
\text { puluh enam pasien di } \\
\text { atas } 18 \text { tahun dengan } \\
\text { retensi bekuan darah } \\
\text { yang dirujuk ke layanan } \\
\text { urologi selama periode } \\
3 \text { tahun dimasukkan } \\
\text { dalam penelitian ini. } \\
\text { Protokol standar untuk } \\
\text { MBW dipatuhi untuk } \\
\text { semua pasien yang } \\
\text { pernah dirujuk ke } \\
\text { layanan urologi. } \\
\text { Protokol ini diuraikan } \\
\text { dan diringkas oleh } \\
\text { akronim CATCH-22. }\end{array}$ & $\begin{array}{l}\text { Sebuah kateter balon Foley dengan } \\
\text { ujung bundar bermata dua standar } \\
\text { ukuran } 22 \mathrm{~F} \text { dan syringe piston } 60 \mathrm{~mL} \\
\text { digunakan selama penelitian. } \\
\text { Pengaturan untuk pencucian kandung } \\
\text { kemih manual; sebuah jarum suntik } \\
50-60 \mathrm{ml} \text { terpasang pada setidaknya } \\
\text { ukuran } 22 \mathrm{~F} \text { Foley kateter yang } \\
\text { berada di dalam kandung kemih. } \\
\text { Irigasi bertekanan berulang dan hisap } \\
\text { dilakukan melalui sistem ini } \\
\text { menggunakan saline normal steril. } \\
\text { Cairan irigasi dikeluarkan melalui } \\
\text { mata di ujung kateter Foley. Jet } \\
\text { bertekanan ini dihasilkan dengan } \\
\text { kekuatan manual yang hati-hati yang } \\
\text { menghancurkan gumpalan darah dari } \\
\text { dinding kandung kemih. }\end{array}$ & $\begin{array}{l}\text { Dua puluh enam pasien diikuti } \\
\text { dalam penelitian ini dengan usia } \\
\text { rata-rata } 70 \text { (kisaran 55-85). } \\
\text { Pasien dirujuk dari gawat darurat } \\
(42 \%) \text {, tim medis internal (35\%) } \\
\text { atau unit bedah lainnya }(23 \%) \text {. } \\
\text { Sebagian besar pasien (76\%) } \\
\text { menggunakan terapi antiplatelet } \\
\text { atau antikoagulan pada saat } \\
\text { rujukan. MBW awal dilakukan } \\
\text { pada } 20 \text { dari } 26 \text { kasus (77\%) } \\
\text { dengan volume rata-rata } 145 \text { ml } \\
\text { (SD } \pm \text { 125). Irigasi kandung } \\
\text { kemih berkelanjutan (CBI) } \\
\text { dimulai pada } 16 \text { pasien (66\%). } \\
\text { Semua pasien menjalani MBW } \\
\text { standar lebih lanjut oleh layanan } \\
\text { urologi sesuai dengan protokol. } \\
\text { Volume rata-rata MBW urologi } \\
\text { adalah } 5392 \text { ml (SD } \pm 847) . \\
\text { Volume rata-rata bekuan yang } \\
\text { dievakuasi oleh urologi MBW } \\
\text { adalah } 617 \text { ml (SD } \pm 313) . \\
\text { Tes Kruskal-Wallis Chi-squared } \\
\text { digunakan dengan perbedaan } \\
\text { yang signifikan secara statistik } \\
\text { (33,774, df }=1, p<0,001) \text {. }\end{array}$ \\
\hline $\begin{array}{l}\text { Bo et al., (2014) ; China } \\
\text { (16) } \\
\text { Evaluation of Bladder Clots } \\
\text { Using a Nonsurgical } \\
\text { Treatment }\end{array}$ & Clinical trial & $\begin{array}{l}\text { Untuk } \\
\text { memperkenalkan } \\
\text { metode baru agar } \\
\text { berhasil } \\
\text { mengevakuasi retensi } \\
\text { gumpalan parah di } \\
\text { kandung kemih. }\end{array}$ & $\begin{array}{l}\text { Penelitian } \\
\text { melibatkan } 22 \text { pasien } \\
\text { pria (usia } 42-82 \text { tahun) } \\
\text { yang diobati dengan } \\
\text { metode kami dari } \\
\text { Februari 2010 hingga } \\
\text { Oktober 2012. } \\
\text { Etiologi hematuria } \\
\text { seperti cedera terbuka } \\
\text { ginjal kiri pada } 1 \text { pasien } \\
(5 \%) \text { tumor kandung } \\
\text { kemih pada } 3 \text { pasien }\end{array}$ & $\begin{array}{l}\text { - Kelompok Intervensi : } \\
\text { Kandung kemih diirigasi dengan } \\
40.000 \text { U chymotrypsin dalam } 50 \\
\text { mL natrium bikarbonat } 5 \% \\
\text { menggunakan kateter Foley (20F- } \\
24 \mathrm{~F} \text { ) selama } 30 \text { menit. Gumpalan } \\
\text { itu kemudian mudah dimobilisasi } \\
\text { dan dievakuasi menggunakan } \\
\text { irigasi salin terus menerus dan } \\
\text { hisap dengan jarum suntik } 60 \mathrm{~mL} \text {. } \\
\text { Prosedur ini diulangi 2-4 kali } \\
\text { sampai semua gumpalan darah }\end{array}$ & $\begin{array}{l}\text { Dari } 22 \text { pasien, } 19 \text { berhasil } \\
\text { diobati menggunakan metode ini, } \\
\text { dengan retensi bekuan } \\
\text { sepenuhnya terselesaikan. Urin } \\
\text { merah pucat muncul pada } 3 \\
\text { pasien lainnya. Namun, setelah } \\
\text { mengeluarkan kateter Foley, sisa } \\
\text { gumpalan darah kecil dievakuasi } \\
\text { dengan mudah selama buang air } \\
\text { kecil. Tidak ada pasien yang } \\
\text { membutuhkan pembedahan, } \\
\text { prosedur loop resectoscope, atau }\end{array}$ \\
\hline
\end{tabular}




\begin{tabular}{|c|c|c|c|c|c|}
\hline & & & $\begin{array}{l}\text { (14\%), hiperplasia } \\
\text { prostat jinak pada } 3 \\
\text { pasien }(14 \%), \text { cedera } \\
\text { kandung } \\
\text { tertutup pada } 2 \text { pasien } \\
(9 \%) \text {, dan reseksi pasca } \\
\text { transurethral pada } 13 \\
\text { pasien }(58 \%) . \\
\text { pasien } \text { menualami } \\
\text { uroschesis karena } \\
\text { retensi bekuan darah } \\
\text { yang parah. }\end{array}$ & $\begin{array}{l}\text { telah dievakuasi. } \\
\text { - Kelompok Kontrol : - (tidak ada) }\end{array}$ & $\begin{array}{lr}\text { bahkan evakuasi Ellik. Setelah } \\
\text { prosedur, pasien tidak memiliki } \\
\text { keluhan berkemih } r \text { atau } \\
\text { ketidaknyamanan } & \text { kandung } \\
\text { kemih. } & \end{array}$ \\
\hline $\begin{array}{l}\text { Mesfin et al., (2011) ; USA } \\
(17) \\
\text { Catheter Design for } \\
\text { Effective Manual Bladder } \\
\text { Irrigation }\end{array}$ & $\begin{array}{l}\text { Experimental } \\
\text { Study }\end{array}$ & $\begin{array}{l}\text { Untuk } \\
\text { membandingkan } \\
\text { efisiensi } \\
\text { pembersihan } \\
\text { gumpalan simulasi } \\
\text { dari model kandung } \\
\text { kemih menggunakan } \\
\text { kateter irigasi 6- } \\
\text { lubang, kateter } \\
\text { Malecot tradisional } \\
\text { dan kateter Malecot } \\
\text { yang dimodifikasi } \\
\text { dengan lubang } \\
\text { samping tambahan. }\end{array}$ & $\begin{array}{l}\text { Penelitian ini tidak } \\
\text { memiliki partisipan }\end{array}$ & $\begin{array}{l}\text { Balon lateks berdiameter } 12 \text { inci } \\
\text { berfungsi sebagai model kandung } \\
\text { kemih. Kemudian diisi dengan gelatin } \\
\text { Jell-O® } 300 \mathrm{cc} \text {, yang telah dipadatkan } \\
\text { sebagian selama } 8 \text { jam di 36F. Lima } \\
\text { siklus irigasi / aspirasi manual } \\
\text { dengan jarum suntik ujung kateter } 60 \\
\text { cc dilakukan untuk menghilangkan } \\
\text { bekuan darah tiruan dari model } \\
\text { kandung kemih dan jumlah bekuan } \\
\text { darah diukur. Lima model kandung } \\
\text { kemih digunakan untuk menguji } \\
\text { efisiensi pelepasan gumpalan untuk } \\
\text { setiap desain kateter } 22 \mathrm{Fr} \text {, termasuk } \\
22 \text { Fr Model standar } 361222 \text { Kateter } \\
\text { lateks 4-sayap Malecot (Rusch, High } \\
\text { Wycombe, United Kingdom) dan } 22 \mathrm{Fr} \\
\text { Bardex@ Model } 606118-22 \text { lateks } 6 \text { - } \\
\text { lubang kateter. Dua versi modifikasi } \\
\text { dari desain kateter Malecot yang } \\
\text { melibatkan } 2 \text { dan } 4 \text { lubang tambahan } \\
\text { juga diuji untuk menentukan efek dari } \\
\text { desain hybrid 6-hole / Malecot. }\end{array}$ & $\begin{array}{l}\text { Kateter 6-lubang lebih efisien } \\
\text { untuk evakuasi bekuan daripada } \\
\text { kateter Malecot (p 0,014). Kateter } \\
\text { Malecot yang dimodifikasi } \\
\text { dengan } 4 \text { lubang tambahan lebih } \\
\text { efisien daripada kateter Malecot } \\
\text { asli (p 0,020). Namun, itu tidak } \\
\text { jauh lebih baik daripada kateter } \\
\text { 6-lubang. Setelah } 5 \text { siklus irigasi / } \\
\text { aspirasi, } 77,0 \% \text { residu bekuan } \\
\text { darah tetap berada dalam } \\
\text { kandung kemih dengan kateter } \\
\text { Malecot dibandingkan dengan } \\
60,4 \% \text { dan } 54,0 \% \text { untuk kateter } \\
\text { Malecot } 6 \text { lubang dan } 4 \text { lubang } \\
\text { yang dimodifikasi secara } \\
\text { berturut-turut. }\end{array}$ \\
\hline
\end{tabular}




\section{Daftar Pustaka}

1. Ritch CR, Ordonez MA, Okhunov Z, Araujo J, Walsh R, Baudin V, et al. Pilot study of Alteplase (tissue plasminogen activator) for treatment of urinary clot retention in an in vitro model. J Endourol. 2009 Aug;23(8):1353-7.

2. Clarebrough E, McGrath S, Christidis D, Lawrentschuk N. CATCH-22: a manual bladder washout protocol to improve care for clot retention. World J Urol [Internet]. 2018;36(12):2043-50. Available from: https://doi.org/10.1007/s00345-018-2346-z

3. Aydin C, Senturk AB, Akkoc A, Topaktas R, Aydın ZB, Ekici M. Clot Retention: Our Experiences with a Simple New Technique of Evacuation with a Thoracic Catheter. Cureus. 2019;11(3):1-10.

4. Goudra BG, Singh N. Transurethral Resection of Prostate (TURP). Essence Anesth Pract. 2011;16:556.

5. Purnomo B. Dasar-Dasar Urologi. Edisi 3. Jakarta: Sugeng Seto; 2011.

6. Reddi D. Preventing chronic postoperative pain. 2016;71:64-71.

7. McVary KT, Roehrborn CG, Avins AL, Barry MJ, Bruskewitz RC, Donnell RF, et al. Update on AUA guideline on the management of benign prostatic hyperplasia. J Urol. 2011;185(5):1793-803.

8. Vuichoud C, Loughlin KR. Benign prostatic hyperplasia: epidemiology, economics and evaluation. 2015;(October):1-6.

9. Edlin RS, Heyns CF, Van Vuuren SPJ, Zarrabi AD. Prevalence of histological prostatitis in men with benign prostatic hyperplasia or adenocarcinoma of the prostate presenting without urinary retention. South African J Surg. 2012;50(4):127-30.

10. ACI Urology Network. Bladder Irrigation : Management of Haematuria. 2019;2.

11. Moher D, Liberati A, Tetzlaff J, Altman DG, Group P. Preferred reporting items for systematic reviews and meta-analyses : the PRISMA statement. Int J Surg, 8, 336-41. 2010;

12. CASP. CASP 2018: Randomised Controlled Trial Checklist. 2018;(2018). Available from: www.casp-uk.net

13. CASP. CASP 2018: Cohort Study Checklist. 2018;(2018):1-7. Available from: http//:www.casp-uk.net

14. Goel A, Dalela D. Mechanical Suction For Clot Evacuation: Experience With "Suction Bridge" For Safe And Effective Clot Removal. Int Urol Nephrol. 2015;47(5):723-6.

15. Ding A, Cao H, Wang L, Chen J, Wang J, He B. A Novel Automatic Regulatory Device for Continuous Bladder Irrigation Based on Wireless Sensor in Patients after Transurethral Resection of the Prostate: A Prospective Investigation. Medicine (Baltimore). 2016;95(52).

16. Bo J, Yangyang Y, Jiayuan L, Siwen D, Yong C, Junbo Y. Evaluation of bladder clots using a nonsurgical treatment. Urology [Internet]. 2014;83(2):498-9. Available from: http://dx.doi.org/10.1016/j.urology.2013.09.022

17. Mesfin S, Sarkissian C, Malaeb B, Monga M. Catheter design for effective manual bladder irrigation. J Urol [Internet]. 2011;186(6):2307-9. Available from: http://dx.doi.org/10.1016/j.juro.2011.07.080

18. Kleier JA. Procedure competencies and job functions of the urologic advanced practice nurse. Urol Nurs. 2009;29(2):112-7.

19. Dungerwalla M, Davies N, Perera M, Papa N, Lawrentschuk N. washouts kandung Manual untuk kemih retensi bekuan : survei pengetahuan di kalangan pekerja kesehatan. 2016;

20. Bagheri M, Tahmasebi M, Najafi S, Rafsanjani ZJ. Using hydrogen peroxide as a bladder irrigation solution for clot evacuation. J Pharm Care [Internet]. 2017 Mar 15;3(3-4 SE-Case Report(s)). Available from: http://jpc.tums.ac.ir/index.php/jpc/article/view/84 